\title{
CHLOROQUINE AND HYDROXYCHLOROQUINE: POTENTIALLY INAPPROPRIATE MEDICATIONS FOR OLDER ADULTS?
}

\author{
Cloroquina e hidroxicloroquina: medicamentos \\ potencialmente inapropriados a idosos? \\ Milton Gorzonia
}

INTRODUCTION: Potentially inappropriate medications (PIMs) for older adults cause more adverse effects than benefits. The 2019 American Geriatrics Society Beers Criteria (2019BC) considered five clinical situations as PIM use in older adults. Can drug analysis, according to these situations, assist in the act of making prescriptions for older people? Seeking a practical example for this question, we assessed drugs currently questioned as to their safe use among older people. OBJECTIVE: To check if chloroquine and hydroxychloroquine fit the PIM criteria for older adults and whether this analysis is clinically applicable. METHODS: We systematized the objective based on the five clinical situations defined as PIM use in older adults by the $2019 \mathrm{BC}$. RESULTS: Chloroquine and hydroxychloroquine fulfill, respectively, four and five of these clinical situations. This evaluation allowed the likely definition of these drugs as PIMs for older adults in a simple way, based on a brief analysis of the available literature. CONCLUSION: Chloroquine and hydroxychloroquine may be considered PIMs for older adults. We expect that this analysis can be replicated with other drugs and reduce iatrogenesis in older people.

KEYWORDS: aged; potentially inappropriate medications; chloroquine.

INTRODUÇÃO: Medicamentos potencialmente inapropriados a idosos (MPII) provocam mais efeitos adversos do que benefícios. Os critérios de Beers (CB) da American Geriatrics Society 2019 (CB2019) consideraram cinco situações clínicas como MPII. A análise de medicamentos por essas situações pode auxiliar na prescrição a idosos? Procurando exemplo prático dessa questão, optou-se por análise de fármacos atualmente questionados quanto ao seu uso seguro em idosos. OBJETIVO: Verificar se cloroquina e hidroxicloroquina se enquadram como MPII e se essa análise é aplicável clinicamente. METODOLOGIA: Sistematizou-se o objetivo pelas cinco situações clínicas definidas como MPII pelos CB2019. RESULTADOS: Ambos os fármacos preenchem respectivamente quatro (cloroquina) e cinco (hidroxicloroquina) dessas situações clínicas. Esta análise permitiu a provável definição de MPII para esses medicamentos de forma simples, por intermédio de breve análise de literatura acessível. CONCLUSÃO: Cloroquina e hidroxicloroquina podem ser considerados MPII. Espera-se replicar essa análise para outros medicamentos e reduzir iatrogenias em idosos.

PALAVRAS-CHAVE: idoso; medicamentos potencialmente inapropriados; cloroquina.

aSchool of Medical Sciences at Santa Casa de São Paulo - São Paulo (SP), Brazil.

Correspondence data

Milton Gorzoni - Irmandade da Santa Casa de Misericórdia de São Paulo - Rua Primeiro de Janeiro, 396, ap. 51 - Vila Clementino - CEP: $04044-060$ - São Paulo (SP), Brasil. E-mail: gorzoni@uol.com.br

Received on: 06/26/2020. Accepted on: 08/22/2020

https://doi.org/10.5327/Z2447-212320202000074 


\section{INTRODUCTION}

Potentially inappropriate medications (PIMs) for older adults are defined as drugs more likely to cause adverse effects than benefits in patients from this age group..$^{1-4}$ Aiming at assisting clinical practice, several consensus documents were created for PIMs for older adults. The most significant among them is the Beers Criteria (BC), which is periodically updated (1991, 1997, 2003, 2012, 2015, and 2019). ${ }^{1-3}$ The latest BC updates considered five clinical situations as determinants for the inclusion of drugs as PIMs for older adults. ${ }^{2,3}$

These criteria intend to improve the selection of drugs, educate professionals and patients, reduce side effects, act as a tool to evaluate the quality of care, develop standards for drug prescription, and assist health policy-makers. ${ }^{3}$

Can the five clinical situations of the BC help clinical practice and provide security to the prescriber, particularly when the prescription is for older adults? Seeking a practical example for the question above, we analyzed two drugs - chloroquine and hydroxychloroquine - due to the current infectious and epidemiological scenario, as the debate about the safety of these medications for older adults is frequent.

This study aimed at checking whether chloroquine and hydroxychloroquine can be considered PIMs for older adults, and if the process used in this analysis can be replicated in daily clinical practice.

\section{METHODS}

We systematized the question previously presented according to the five clinical situations defined as PIM use in older adults by the BC. ${ }^{2,3}$

- PIMs for most older adults;

- Medications that should be usually avoided by older adults with specific clinical conditions;

- Medications that should be used with caution in this age group;

- Medications with known drug interaction;

- Medications that require dose adjustment based on the degree of renal dysfunction.

The literature search was conducted in the portals https://pubmed.ncbi.nlm.nih.gov/ and https://scielo. org/, with the keywords: "Chloroquine and the Elderly", "Hydroxychloroquine and the Elderly", "Chloroquine and Older Person", "Hydroxychloroquine and Older Person".

The exclusion criterion was publications focused on the use of these two drugs in the current infectious and epidemiological scenario. We sought articles addressing their side effects, drug interactions, and/or contraindications in older adults.

\section{RESULTS}

Potentially inappropriate medications for most older adults

The high prevalence of rheumatic diseases in older adults creates the risk of progressive loss of functional independence, thus leading to the use of antirheumatic drugs. The continuous use of non-steroid anti-inflammatory drugs should be avoided in older people, regardless of their clinical condition, ${ }^{1-3}$ due to the risk of gastrointestinal bleeding, increase in arterial hypertension, decompensated heart failure and/or chronic kidney disease, and delirium. ${ }^{1-3}$

Chloroquine and hydroxychloroquine are also used as antirheumatic drugs. The first has the following precautions in case of prescription:

- caution when administering to patients with kidney failure;

- higher risk of retinal lesions;

- small safety margin (three times the therapeutic dose in adults treated for malaria can be lethal if administered in a single dose)..$^{5}$

Also, some reports reveal side effects, such as irritability, emotiveness, and psychosis in doses higher than $6 \mathrm{mg} / \mathrm{kg} /$ day of hydroxychloroquine. ${ }^{6}$ The PIM criteria consulted do not regard chloroquine or hydroxychloroquine as inappropriate for most older adults. ${ }^{1-3} \mathrm{We}$ assume that this fact results from the formal indications for these medications: antimalarial drugs and to treat cases of rheumatoid arthritis and discoid and systemic lupus erythematosus in patients who have not satisfactorily responded to medications with less potential for side effects.

In addition to the effects described above, the glomerular filtration rate (GFR) decreases with advancing age in the proportion of $6.30 \mathrm{~mL} / \mathrm{min} / 1.73 \mathrm{~m}^{2}$ per decade of life, a significant factor for the prescription of drugs with renal excretion. $^{7}$

Equal attention should be paid to macular degeneration, the main cause of amaurosis in individuals aged $\geq 55$ years. Total or partial vision loss is highly debilitating, and drugs that can potentially lead to retinal lesions should have their pros and cons analyzed before being prescribed. ${ }^{8}$

Medications that should be usually avoided by older adults with specific clinical conditions

The use of chloroquine and hydroxychloroquine can result in the development of lysosomal storage disorders. This condition causes drug-induced heart diseases characterized by conduction disorders and cardiomyopathy. As older adults 
often have cardiovascular diseases, and the clinical cardiotoxicity pattern is usually nonspecific, the literature consulted recommends strict identification and follow-up of patients using these drugs due to the risk of severe adverse events and death. ${ }^{9}$

Delirium and dementia are among the main causes of cognitive impairment in the older population. Estimates indicate that 10 to $32 \%$ of adults hospitalized develop delirium during their hospital stay. Usually of multifactorial origin, the manifestation of acute confusional state - particularly in older adults with prior cognitive dysfunction - deserves special attention as to the use of delirium-inducing medications. ${ }^{10}$ Some reports describe psychomotor agitation, irritability, and emotiveness associated with the use of hydroxychloroquine and their - total or partial - reversibility after discontinuing the medicine. ${ }^{6,10}$

\section{Medications that should be used with caution in this age group}

According to the product monograph of the pharmaceutical company that produces hydroxychloroquine sulfate tablets, caution should be observed in patients with gastrointestinal, visual, or neurological disorders, kidney failure, porphyria, psoriasis, risk of hypoglycemia, electrocardiograms with prolongation of the QTc interval, and sensitivity to quinine. ${ }^{11}$

The same monograph mentions caution with older patients when listing the risk factors for cardiac arrhythmia torsade de pointes and periodic ophthalmologic evaluations for early detection of retinopathy. ${ }^{11}$

\section{Medications with known drug interaction}

The portal https:/www.drugs.com/drug-interactions/ chloroquine-index.html presented 378 drug interactions with chloroquine on April 25, 2020, of which 67 were major interactions - high clinical relevance. In these cases, the risk of the interaction outweighs the benefit. Table 1 provides examples of these interactions. ${ }^{12}$

Summarizing the clinical effects of drug interactions with chloroquine, we found a significant number of interactions capable of interfering with the cardiac function, producing hematological changes, causing or aggravating convulsive states, and triggering neurotoxicity. ${ }^{5,6,11}$

The same portal, https://www.drugs.com/drug-interactions/chloroquine-index.html, listed 333 drug interactions with hydroxychloroquine on April 25, 2020, 60 of them being major interactions. The examples cited of drug interactions with chloroquine virtually coincide with those for hydroxychloroquine.
Table 1. Examples of drug interactions with chloroquine obtained in the portal Drugs.com.

\begin{tabular}{|c|c|c|c|}
\hline \multirow{2}{*}{$\begin{array}{l}\text { Major } \\
\text { interactions* } \\
\text { Amiodarone }\end{array}$} & \multicolumn{2}{|c|}{$\begin{array}{c}\text { Moderate } \\
\text { interactions** }\end{array}$} & \multirow{2}{*}{$\begin{array}{c}\text { Minor } \\
\text { interactions*** } \\
\text { Carvedilol }\end{array}$} \\
\hline & Valproic acid & Imipramine & \\
\hline Bupropion & Amitriptyline & Isoniazid & Donepezil \\
\hline Cisapride & Amoxapine & Lamotrigine & Methotrexate \\
\hline Citalopram & Ampicillin & Levodopa & Metoprolol \\
\hline Clozapine & Atorvastatin & Levofloxacin & Propranolol \\
\hline Disopyramide & Carbamazepine & Linezolid & Sulfamethoxazole \\
\hline Droperidol & $\begin{array}{l}\text { Calcium } \\
\text { carbonate }\end{array}$ & Loperamide & \\
\hline Escitalopram & Ketoconazole & Metronidazole & \\
\hline Haloperidol & Ciprofloxacin & Mirtazapine & \\
\hline Methadone & Clarithromycin & Nitrofurantoin & \\
\hline Quinidine & Clomipramine & Norfloxacin & \\
\hline Saquinavir & Chlorpromazine & Nortriptyline & \\
\hline Sotalol & Codeine & Olanzapine & \\
\hline Thioridazine & Digoxin & Ondansetron & \\
\hline \multirow[t]{17}{*}{ Tramadol } & Desipramine & Pancuronium & \\
\hline & Disopyramide & Pravastatin & \\
\hline & Doxepin & Praziquantel & \\
\hline & Dronedarone & Pregabalin & \\
\hline & Duloxetine & Protriptyline & \\
\hline & Ethambutol & Quetiapine & \\
\hline & Famotidine & Risperidone & \\
\hline & Phenytoin & Rivastigmine & \\
\hline & Phenobarbital & Rosuvastatin & \\
\hline & Fluconazole & Sertraline & \\
\hline & Fluoxetine & Simvastatin & \\
\hline & Formoterol & Tamoxifen & \\
\hline & Galantamine & $\begin{array}{l}\text { Timolol } \\
\text { Eye Drops }\end{array}$ & \\
\hline & Ginkgo biloba & Trimipramine & \\
\hline & Halothane & Vasopressin & \\
\hline & Hydralazine & Venlafaxine & \\
\hline & Hydroxyzine & & \\
\hline
\end{tabular}

*High clinical relevance. The risk of the interaction outweighs the benefit; **moderate clinical relevance. Use it only under special circumstances; ${ }^{* *}$ low clinical relevance. Assess the risk, consider an alternative treatment, take steps to monitor and/or reduce the risk of drug interaction.

Source: Drugs.com. ${ }^{12}$ 
We underline that, in some drug interactions with chloroquine and/or hydroxychloroquine, the second drug is considered a PIM for older adults by the 2019 American Geriatrics Society BC. ${ }^{3}$

\section{Medications that require dose adjustment} based on the degree of renal dysfunction

The prescription of drugs with renal excretion must be accompanied by the GFR calculation. This precaution is justified by physiological renal aging. The association of diseases and/or medications able to accelerate this kidney damage process also deserves attention in clinical practice. Considering the low functional reserve in older adults, a significant percentage of patients in this age group have chronic kidney disease and/or risk of acute kidney failure. ${ }^{13}$

Estimates indicate that kidneys excrete $50 \%$ of the dose of chloroquine. Thus, its dosage should be adjusted according to the GFR of the patient. Reducing the daily dose to a maximum of $50 \mathrm{mg}$ in patients with GFR between 10 and $20 \mathrm{~mL} / \mathrm{min}$ and suspending its use when the GFR is lower than $10 \mathrm{~mL} / \mathrm{min}$ are recommended. Since chloroquine presents extensive tissue connection, renal replacement therapies are not useful in excessive doses or drug poisoning. ${ }^{5,14}$

Equal caution should be exercised when prescribing hydroxychloroquine for patients with GFR lower than $60 \mathrm{~mL} / \mathrm{min}$, given the risk of them developing retinopathy secondary to the use of the drug. Another fact reported in situations of renal dysfunction is its neurotoxicity potential and the possibility of causing cardiomyopathies, myopathies, and proximal neuropathies. In order to reduce this risk, the ideal daily dose of hydroxychloroquine is estimated to be between 6.50 and $5 \mathrm{mg} / \mathrm{kg}$ of body weight. ${ }^{15,16}$

\section{DISCUSSION}

The findings exposed in the present analysis about chloroquine and hydroxychloroquine do not end the discussion on whether or not they are PIMs for older adults, as the criteria required for this conclusion would not be restricted to a sole opinion but to a consensus of various experts.

We assumed - as a point to be questioned in this perspective - the risk of data selection bias. This fact resulted from the scarce literature found in the portals consulted addressing the two drugs without the connection with passionate debates involving the current infectious and epidemiological scenario and its therapeutic options.

However, according to the five clinical situations defined as PIM use in older adults by the $\mathrm{BC},{ }^{2,3}$ chloroquine and hydroxychloroquine fulfill respectively four and five of these clinical situations. This finding indicates a real possibility of them being PIMs for older adults.

Considering the rapid population aging process, all health professionals should bear in mind that the effective therapeutic action of the drug prescribed might depend on the physiological changes specific to aging. We also emphasize the number of chronic non-communicable diseases and the use of several drugs simultaneously, which increase the chance of side effects and drug interactions.

This evaluation allowed the likely definition of these drugs as PIMs for older adults in a simple way, based on a brief analysis of the available literature, which can be replicated in daily clinical practice. Hopefully, it can contribute to improving care for older adults.

\section{CONCLUSION}

Based on the current analysis, chloroquine and hydroxychloroquine may be considered PIMs for older adults. We expect that this methodological process can be replicated in clinical practice with other drugs to reduce iatrogenic events in the older population.

\section{CONFLICT OF INTERESTS}

The author declare no conflicts of interest.

\section{FUNDING}

None.

\section{AUTHORS' CONTRIBUTION}

MG: writing - original draft, writing - review and editing.

\section{REFERENCES}

1. Beers MH, Ouslander JG, Rollingher I, Reuben DB, Brooks J, Beck $J C$. Explicit criteria for determining inappropriate medication use in nursing home residents. UCLA Division of Geriatric Medicine. Arch Intern Med. 1991;151(9):1825-32. https://doi.org/10.1001/ archinte.1991.00400090107019
2. American Geriatrics Society 2015 Beers Criteria Update Expert Panel. American Geriatrics Society 2015 Updated Beers Criteria for Potentially Inappropriate Medication Use in Older Adults. J Am Geriatr Soc. 2015;63(11):2227-46. https://doi.org/10.1111/ jgs.13702 
3. 2019 American Geriatrics Society Beers Criteria ${ }^{\circledR}$ Update Expert Panel. American Geriatrics Society 2019 Update AGS Beers Criteria ${ }^{\circledR}$ for Potentially Inappropriate Medication Use in Older Adults. J Am Geriatr Soc. 2019;67(4):674-94. https://doi.org/10.1111/jgs.15767

4. Gorzoni ML, Fabbri RM, Pires SL. Potentially inappropriate medications in elderly. Rev Assoc Med Bras. 2012;58(4):442-6. http://dx.doi. org/10.1590/S0104-42302012000400014

5. Brooks PM, Kean WF, Kassam Y, Buchanan WW. Problems of antiarthritic therapy in the elderly. J Am Geriatr Soc. 1984;32(3):229-34. https:// doi.org/10.1111/j.1532-5415.1984.tb02007.x

6. Mascolo A, Berrino PM, Gareri P, Castagna A, Capuano A, Manzo C, et al. Neuropsychiatric clinical manifestations in elderly patients treated with hydroxychloroquine: a review article. Inflammopharmacology. 2018;26(5):1141-9. https://doi.org/10.1007/s10787-018-0498-5

7. Denic A, Glassock RJ, Rule AD. Structural and functional changes with the aging kidney. Adv Chronic Kidney Dis. 2016;23(1):19-28. https:// doi.org/10.1053/j.ackd.2015.08.004

8. Garralda A. Toxicidad ocular medicamentosa. An Sist Sanit Navar. 2008;31(Supl. 3):147-53. https://doi.org/10.4321/S113766272008000600013

9. Tönnesmann E, Kandolf R, Lewalter T. Chloroquine cardiomyopathy - a review of the literature. Immunopharmacol Immunotoxicol.
2013;35(3):434-42. https://doi.org/10.3109/08923973.2013. 780078

10. Clegg A, Young JB. Which medications to avoid in people at risk of delirium: a systematic review. Age Ageing. 2011;40(1):23-9. https:// doi.org/10.1093/ageing/afq140

11. PrPLAQUENIL ${ }^{\oplus}$ (Hydroxychloroquine Sulfate Tablets USP) $200 \mathrm{mg}$. [Product Monograph]. Laval: Sanofi-Aventis Canada Inc; 2019.

12. Drugs.com. Chloroquine drug interactions. Drugs.com [Internet]. [acesso em 25 abr. 2020]. Disponível em: https://www.drugs.com/ drug-interactions/chloroquine-index.html

13. Sales GTM, Foresto RD. Drug-induced nephrotoxicity. Rev Assoc Med Bras. 2020;66(Supl. 1):S82-S90. https://doi.org/10.1590/18069282.66.s1.82

14. Thorogood N, Atwal S, Mills W, Jenner M, Lewis DA, Cavenagh JD, et al. The risk of antimalarials in patients with renal failure. Postgrad Med J. 2007;83(986):el-e8. https://doi.org/10.1136/pgmj.2007.063735

15. Biehl AJ, Katz JD. Pharmacotherapy pearls for the Geriatrician: Focus on oral disease-modifying antirheumatic drugs including newer agents. Clin Geriatr Med. 2017;33(1):1-15. https://doi.org/10.1016/j. cger.2016.08.001

16. Stein M, Bell MJ, Ang LC. Hydroxychloroquine neuromyotoxicity. J Rheumatol. 2000;27(12):2927-31. 